\title{
Income Distribution in Keynesian Growth Models and Financing of Development Plans
}

\begin{abstract}
AMIT BHADURI*
In the usual format of Keynesian growth models investment governs saving: higher investment causes more profits either through greater capacity utilization (normal 'multiplier') or through rising prices ('profit inflation') which, in turn, generates the matching level of savings. The present paper argues that such methods of financing higher investment plans are neither socially desirable nor even sustainable over time in an underdeveloped mixed economy. Consequently, alternative institutional and financial arrangements, where a crucial role is assigned to a public distribution system of essential goods and profits of public enterprises, becomes imperative.
\end{abstract}

Keynes took over from Marshall the analytical distinction between 'firms' and 'households' as prototypes of the two major economic agents in a modern industrial society. In Marshall's scheme, firms as producing units and households as consuming units were subject to what became text-bookish micro-economic analysis of 'rational behaviour'. For formulating his theory of effective demand, Keynes made a departure from the Marshallian scheme by emphasizing the role of firms as investing units and that of households as saving units. It will be recalled that this led to the crucial separation between investment and saving decisions, which came to be recognized as a distinguishing feature of Keynesian economics.

In a more fundamental political sense, both Marshall and Keynes accepted the 'liberal view' of a modern industrial society, where households are treated as a more or less homogeneous category of income recipients. No essential distinction had to be drawn between capitalist households that earn their income from property ownership and working-class households that earn their income from work. ${ }^{1}$ This is perhaps most clearly exhibited in the Keynesian assumption of undifferentiated saving (and consumption) function, which simply depends on the total level of income received by households, but not on its distribution between profits and wages.

*The author is a Professor at the Centre for Economic Studies and Planning, Jawaharlal Nehru University, New Delhi (India).

${ }^{1}$ From this point of view, Keynes's earlier Treatise is more discriminating than the General Theory! 
Harrod's classic paper [1], trying mainly to set the ideas of the General Theory in the context of long-period accumulation, also tended to accept the same liberal view of a homogeneous household sector. Indeed, the nature of his knife-edge equilibrium between the actual and the warranted rate of growth ${ }^{2}$ crucially hinges on the assumption of an invariant aggregate propensity to save out of income that is indepenent of the class distribution of income between profits and wages.

There is now a familiar argument advanced by post-Keynesian economists which returned to the 'classical' idea that savings mostly come from profits and, consequently, the overall savings ratio increases as income distribution shifts in favour of profits. $^{3}$ Their argument closely follows the causal connexions suggested in the General Theory, but far more explicitly brought out in the writings of Kalecki, that proceeded independently of the General Theory [4, especially essay 7]. In this scheme of analysis, investment is the independent, active variable whose level is determined by the expectations of firms of future profits. And firms can maintain whatever is their decided level of investment expenditure, mainly through easy access to commercial banks for credit, in relation to the lending rate of the banks. Savings is the dependent, passive variable which adjusts to higher investment either through an expansion of the level of income or through a redistribution of income in favour of profits or some amalgam of both. ${ }^{4}$

Consider now a higher level of investment associated with a higher actual rate of growth in the Harrodian sense. If this entails a higher proportion of savings in national income through 'profit inflation's, i.e. through a redistribution of income in favour of profits against wages, then the Harrodian warranted rate of growth will also tend to be higher, resulting in a tendency to match the actual with the warranted rate of growth. A mechanism based on variation in class distribution of income tending to adjust profits then comes into operation to blunt the knife-edge of the equilibrium between the actual and the warranted rate originally postulated by Harrod. ${ }^{6}$

${ }^{2}$ In later versions of growth models of the neo-classical variety, the question itself was changed to examine adjustment between warranted (or actual) and natural rates of growth. The underlying reason was the 'pre-Keynesianism' of neo-classical models, which did not highlight the independent role of investment and simply assumed (as in Say's Law) that all savings are automatically invested so that warranted and actual growth rates never differ. See, for example, $[7]$ and $[8]$ as the two early influential articles along this line.

${ }^{3}$ In symbols, the simplest way to put this is to assume that all wages are consumed so that,

$\frac{\mathrm{S}}{\mathrm{Y}}=\mathrm{s}=\mathrm{s}_{\mathrm{p}} \cdot \frac{\mathrm{P}}{\mathrm{Y}}=\mathrm{s}_{\mathrm{p}} \mathrm{h}$.

where $s_{p}=$ savings propensity out of profit income, and

$\mathrm{h}=$ share of profit in income.

Given $\mathrm{s}_{\mathrm{p}}$, the overall savings ratio $\mathrm{s}$ increases with $\mathrm{h}$.

${ }^{4}$ Using notations of footnote 3 , we can write $I=S=s_{p} h Y$, so that, given $s_{p}$, either $\mathrm{Y}$ or $\mathrm{h}$ (or both) adjusts upward to generate enough saving to match a higher level of investment.

${ }_{6}^{5}$ To borrow a term from Keynes's, Treatise which first presented this idea.

${ }^{6}$ 'See [5] and [6]. This class of growth models are intimately linked with the socalled 'Cambridge distribution theory' originating in Keynes's, Treatise and reformulated in [3].
This view of capitalistic accumulation in a Keynesian setting seems instructive for two rather opposite reasons. Firstly, it provides a clear analytical formulation of the Classical idea that income distribution among classes is crucial to understanding the process of economic growth. Indeed, by making income distribution the central adjusting variable through which investment generates its own savings, this class of growth models revives the classical idea that the process of economic growth is intimately linked with the process of income distribution. Secondly, it also rescues the theory of capitalistic accumulation from the fallacy of Say's law. It is a common misinterpretation of Harrod's formulation to suggest that a higher proportion of savings to income necessarily means a higher actual rate of growth. By emphasizing the causal link that investment governs savings, this class of growth models is able to highlight the crucial feature that it is the warranted rate of growth that will adjust to a higher independently given actual rate of growth through increased savings to income ratio. But a higher warranted rate of growth will not necessarily lead to a higher actual rate of growth, when the willingness to invest is sluggish on the part of the capitalists. In more conventional terms, this will mean that savings plans (guiding the warranted rate) are not matched by sufficiently vigorous investment plans (guiding the actual rate), so that the level of effective demand will slide back to make savings plan adjust downwards to a lower actual rate of accumulation.

This seems to provide an important lesson for formulating development plans that take income distribution seriously. Attempts to increase the savings rate in isolation through fiscal and monetary measures may not be favourable for the growth process, unless it is also coupled with a matching higher investment plan. Under completely centralized planning this may not present much of a problem. But under partial planning in a mixed economy, the problem can be serious enough. Imagine various kinds of 'pro-capitalist' fiscal measures like 'tax-holidays', generous depreciation allowance, tight control on collective bargaining for wage increases, etc. Insofar as these policies succeed in increasing the profit component of value added in organized industry, they may generally be expected to raise the corporate savings ratio and, consequently, the 'warranted rate' of industrial growth in a mixed economy. But it is far from certain that this higher warranted rate will be realized into a correspondingly higher actual rate of growth, unless the climate for private investment improves sufficiently fast to generate investment plans that are large enough to absorb that higher savings potential (caused by those policies aimed at maintaining a larger profit component in value added). Since the climate for private investment can generally be expected to improve at best only slowly in response to favourable fiscal and monetary policy measures, the 'traverse' to a higher rate of actual growth is far from certain. ${ }^{7}$ In brief, any rapid traverse to a higher actual growth path through

${ }^{7}$ In other words, the high share of profits in value added will not be fully realized due to lack of effective demand, as part of the profit may remain in the form of unplanned accumulation of inventories. This may result in lower actual growth resulting from lower investumulathe next period, in view of such accumulated inventories. 
vigorous private investment can be more or less ruled out, except when the climate for private investment improves with remarkable speed.

Conventional planning wisdom, therefore, has little option but to rely heavily on public investment in a mixed economy. But the dilemma here can go deeper. Following the Keynesian argument, if the planners 'leave it to the market' to generate enough savings to match the higher level of public investment, then the social consequences of the resulting 'profit inflation' may become altogether unacceptable. For higher public investment may generate higher private profits in the corporate sector so that, in effect, a deteriorating process of income distribution is resorted to for financing that higher level of public investment. Indeed, such a development strategy is unlikely to be viable over time. For higher corporate profits will also typically entail higher expenditure on 'luxury consumption' and the increased profitability in luxury consumption-goods production must sooner or later begin to affect the pattern of investment itself. In brief, higher public investment financed through savings from higher corporate profits will gradually result in losing control over the content of the growth process itself.

An important negative message, therefore, seems to emerge from this class of Keynesian growth models, which is relevant in formulating development plans. Financing the higher level of public investment through 'profit inflation', which is a characteristic feature of the market economy, is unlikely to succeed in general. The growth process will become unsustainable through generation of demand for luxuries and it will, at the same time, become socially unacceptable through gradual worsening of income distribution. It therefore seems unavoidable that the planning strategy must involve a two-pronged attack: it must consist not only of an investment plan, but also of a plan for controlling th process of income generation. Formulation of a well-balanced investment plan is primarily a technocratic exercise; but controlling the process of income generation is predominantly a matter of political feasibility. Not surprisingly, it is on this latter point that Indian (and perhaps, most other South Asian) planning experience has been systematically weak.

It is not even always recognized that there are two broad alternatives in controlling the process of income generation in a 'mixed' economy. The first alternative relies on conventional fiscal and monetary measures. The essential characteristic of this alternative is not to interefere with the income generation process dictated by the market, but to moderate it as far as possible at the post-tax stage. The other alternative is to attempt to change the very process of income generation itself. In the extreme, it involves changes in property relations; but there are some interim short-term measures that can go a long way in influencing the process of income generation in the desired direction. A system of public distribution of essential commodities (that are likely to be most sensitive to 'profit inflation') is an important case in point; for it will control the volume of trading profits that may otherwise be associated with an amibitious public investment programme. Similarly, making profits from public enterprises - an important source of government revenue - may be another example. For the larger the extent of self-financing of the public sector, the lesser the pressure for financing investment through 'profit inflation' of Keynesian
type. These are some relatively short-term instrutor, the income generation, which must be seriously instruments for controlling the process of

The formulation of

illuminating example in this respect [2]. It contained of India provides an extremely lations indicating the link between [2]. It contained a most interesting set of calcuresulting investment plan (and their technical virtuosity, its (and their foreign exchange implications). But in spite of the desirable changes in in In short, the method of brought about and sustained. as an open question. But this is an largely left political answer. Planning this is an economic question which admits only of a ically inadequate without that answer.

\section{REFERENCES}

1. Harrod, R. F. "An Essay in Dynamic Theory". Economic Journal. Vol. 49. 1939.

2. India. Planning Commission. Approach to the Fifth Plan 1974 79 . New Delhi. January 1973.

3. Kaldor, N. "Alternative Theories of Distribution" Review of Economic Studies. Vol. 23. 1955-56.

4. Kalecki, Michael. Selected Essays in the Dynamics of the Capitalist Economy. Cambridge: Cambridge University Press. 1971.

5. Khan, R. F. "Exercises in the Analysis of Growth", Oxford Economic Vol. 11. 1959.

6. Robinson, Joan. “A Simple Model of Accumulation". In her Essays in the

7heory of Economic Growth. London : Macmillan. 1962. terly Journal of Economics. Vol 70. 1956.

8. Swan, T. W. "Economics. Vol. 70. 1956.

Record. Vol. 32. 1956. 